Марков О. С. Злигорев В. М. Іванова Ю. О. Лагер О. О. Дорофсєв В. 0.

\title{
УДОСКОНАЛЕННЯ ТЕХНОЛОГІЇ ВИГОТОВЛЕННЯ КРУПНИХ ПОКОВОК НА ОСНОВІ ВИКОРИСТАННЯ НОВОГО СПОСОБУ ОСАДЖЕННЯ
}

Значний обсяг експорту України забезпечує важке і енергетичне машинобудування. Конкурування на міжнародних ринках вимагає підвищення якості та зниження собівартості виробленої продукції. Крупногабаритні деталі у важкому машинобудуванні виготовляються куванням злитків. Метал злитка має низькі механічні властивості, які є наслідком дендритної структури і вадами усадочного походження. Усунути дендритну структуру і заварити внутрішні порожнечі злитка можна, якщо виготовляти поковки з високим уковом. Для цього в технологічному циклі кування використовується ковальське осадження заготовки. Однак в літературі можна зустріти суперечливу інформацію про вплив операції осадження на заварювання внутрішніх пустот. Актуальним напрямом досліджень є вдосконалення операції осадження, яке можна здійснити за рахунок зміни форми заготовки, що осаджуються. Це дозволить змінити деформований і напружений стан заготовки, що підвищить проробку литої структури і якість поковок в цілому [1].

Авторами роботи [1] запропонований спосіб і оснащення для осадження дисків з бобишкою. Осадження проводиться із застосуванням операції розгонки поля диску. Обмеженням цього методу осадження $є$ те, що інструмент не перекриває все поле диска - залишаються непродеформовані ділянки з утворенням затисків, що призводить до збільшення витрати металу при механічній обробці.

MCE було вивчено заковування внутрішніх дефектів при осадженні заготовок плоскими плитами з різною геометрією [2]. На основі скінчено-елементного аналізу автори встановили, що ступінь деформації має більший вплив на закриття порожнин, ніж гідростатичний тиск. Отримані результати суперечать відомим даними інших дослідників [3], які стверджують, що ступінь заковування осьової пористості залежить від НДС в поковках.

Підвищити проробку структури поковок при осадженні можна, використовуючи спосіб, що передбачає біллетування і осадження заготовки. При біллетуванні торцям заготовки надають форму конуса [4]. Обмеження способу полягає в складності отримання конічних торців заготовки, більш того в роботі не встановлено НДС та механізм заковування внутрішніх пустот при куванні.

Автори робіт $[5,6]$ досліджували вплив гідростатичного тиску як параметра для оцінки заковування внутрішніх дефектів. Однак автори в своїх роботах не розглядали розподіл деформацій в об'ємі заготовки при куванні. Оцінити ступінь закриття внутрішніх дефектів можна тільки на підставі комплексного врахування напружень і деформацій заготовки при деформуванні.

В роботі [7] вивчався механізм заковування внутрішніх пустот, що мають сферичну форму. Автори досліджували вплив розмірів пустот на їх закриття. В результаті було визначено, що НДС навколо внутрішніх дефектів є основним фактором, що впливає на закриття порожнин. Запропоновано модель для прогнозування закриття порожнин в крупних заготовках в процесі кування, яка була заснована на результатах скінчено-елементного моделювання. Основним недоліком цього дослідження $є$ використання штучних дефектів сферичної форми, а осьові дефекти злитків мають подовжену форму.

В роботі [8] досліджувався розподіл деформацій в процесі кування зразків циліндричної форми при різних ступенях обтискання. Встановлено залежність механізму накопичення мікропошкоджень на бочці заготовки. У статтях $[9,10]$ розроблено рекомендації, які сприяють підвищенню якості поверхні крупногабаритних поковок. Однак в роботах не розглянуто вплив напруженого стану на утворення тріщин на поверхні, що є важливою науково-практичною проблемою при осаджені злитків. 
В роботі [11] порівнюються два способи моделювання поведінки осьової пористості злитка в процесі кування, які враховували накопичення пошкоджень у пластичнодеформованому тілі, на основі використання моделі пористого матеріалу. Було визначено, що нижній кут вирізу бойків повинен бути в діапазоні $90-120^{\circ}$ для кращого заварювання осьової пористості злитка. Однак досліджені схеми не забезпечують появу у тілі заготовки рівномірних деформацій. При куванні крупногабаритних поковок із злитків дуже важливо забезпечити високу рівномірність деформацій, щоб гарантувати ізотропію механічних властивостей.

В процесі осадження для заварювання внутрішніх дефектів злитка в осьовій зоні необхідно забезпечити стан нерівномірного всебічного стискання. На сьогоднішній день застосовуються варіанти осадження, що не забезпечують достатній рівень напружень, що стискають в місці розташування осьової пористості злитка для підвищення щільності металу поковки [12].

На основі досліджень, представлених в роботі [13], було визначено, що для заварювання внутрішніх пустот злитка необхідно використовувати операцію протягування перед осадженням. Авторами запропонований фактор для оцінки ступеня заварювання внутрішніх дефектів в процесі гарячого деформування, який враховує нерівномірність напруженого стану та розподілу середніх напружень в процесі осадження. Операція осадження без попереднього протягування збільшує розміри осьових дефектів. У роботі авторами не встановлено вплив форми бойків на нерівномірність проковування структури металу.

Головним фактором, на думку авторів роботи [14], який визначає проковування структури і властивості майбутньої деталі, є уков. Однак аналіз різних варіантів кування необхідно робити за даними розподілу накопиченої деформацій в об'ємі заготовки. Це не було зроблено в цій роботі.

Характерними дефектами для кованих заготовок, які зазнають операцію осадження, $\epsilon$ несуцільність осьової зони поковки, яка визначається ультразвуковим контролем (УЗК). Причиною утворення осьової несуцільності металу може служити операція осадження циліндричної заготовки.

На основі літературного огляду встановлено, що вдосконалення техпроцесів кування з використанням спеціального способу осадження чотирипроменевих заготовок представляє важливе наукове і практичне значення, що підтверджує актуальність роботи. Більш того, існуючі способи осадження не забезпечують високих і ізотропних механічних властивостей осьової зони деталі через неповне заковування внутрішніх дефектів злитка, що вимагає проведення подальших досліджень в цьому напрямку. Одним із напрямів удосконалення операції осадження є застосування профілювання заготовки перед осадженням [1]. Однак, в роботі встановлено, що грані з кутом $120^{\circ}$ не сприяють повному закриттю осьової рихлості і збільшення глибини граней при цьому куті знижує ступінь заварювання внутрішніх дефектів. Тому слід проводити подальші дослідження для визначення ефективних кутів і глибини граней чотирипроменевої заготовки, що дозволить інтенсифікувати заковування внутрішніх дефектів.

Метою роботи $є$ удосконалення технології кування поковок відповідального призначення на основі вдосконалення операції осадження чотирипроменевих злитків.

Для вирішення зазначеної мети в роботі поставлені наступні задачі:

- розробити методику досліджень операцій осадження чотирипроменевих заготовок;

- розробити новий науково-обгрунтований спосіб осадження чотирипроменевих заготовок, який підвищує щільність будови поковок;

- на основі проведених комплексних теоретичних і експериментальних досліджень розробити технологічні та конструкторські рекомендації з проектування техпроцесів деформування за новими схемами деформування і інструменту для профілювання злитків.

Моделювання процесу осадження профільованих на чотирипроменевий переріз заготовок проводилось методом скінчених елементів (МСЕ). За результатами моделювання встановлювалось формозмінення штучного дефекту після деформування. Після профілювання усі заготовки осаджувалися на 50 \%. Рівняння зв'язку компонент швидкостей напружень і деформацій. 
Моделі для скінчено-елементного моделювання мали такі розміри (рис. 1): зовнішній діаметр заготовки $\mathrm{D}=1,5 \mathrm{M}$, висота заготовки $\mathrm{H}=3,75 \mathrm{M}$, діаметр отвору дефекту приймався $10 \%$ від зовнішнього діаметру заготовки $\left(0,15\right.$ м), кут граней заготовки становив $150^{\circ}$. Глибина увігнутих граней $(d / D)$ досліджувалась у діапазоні $15 \%, 20 \%$ та $25 \%$ від діаметру заготовки. Матеріал - сталь 70ХЗГНМФ, температура нагрівання заготовки $1150{ }^{\circ} \mathrm{C}$, температура інструменту $20{ }^{\circ} \mathrm{C}$, коефіцієнт тертя 0,45, сітка містить 75000 елементів, швидкість деформування 35 мм / с.

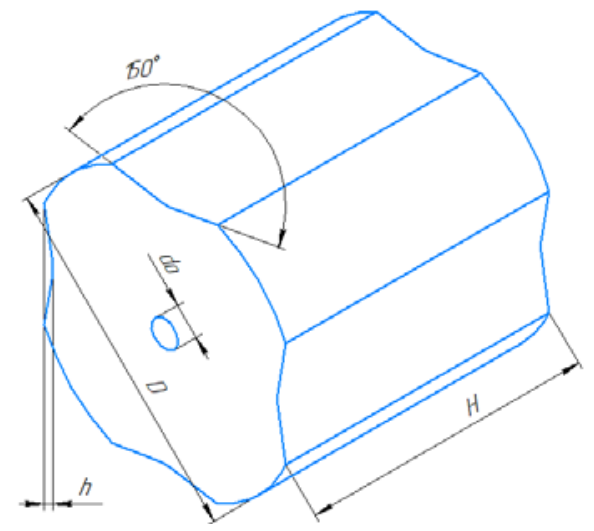

Рис. 1. 3D-модель профільованої заготовка на чотирипроменевий переріз

Для проведення експериментальних досліджень були виготовлені свинцеві заготовки циліндричної форми діаметром 50 мм і висотою 70 мм. На торці заготовки в осьовій їі зоні висвердлювався отвір діаметром 5 мм, який імітував осьовий дефект злитка. Після цього проводилося деформування отриманих заготовок опуклим інструментом, кут опуклих бойків 3 клиновим профілем становив $150^{\circ}$. В процесі профілювання виконувалися виміри поперечного перерізу імітованого дефекту. Отвір дефекту підключався до лабораторної бюретки. Зміна рівня рідини у бюретці дозволяла визначити поточний об'єму дефекту при деформуванні, а далі його середній діаметр.

Після профілювання на чотирипроменевий переріз отримані заготовки осаджували плоскими плитами на ступінь деформації 70 \% 3 поетапним фіксуванням (кожні 5 мм) зміни об'єму дефекту. Дослідження закриття отвору додатково проводилося на зразках зі сталі 70ХЗГНМФ. Сталеві заготовки нагрівалися до температури $1150{ }^{\circ} \mathrm{C}$ та профілювалися на чотирипроменевий переріз опуклим інструментом 3 клиновим профілем 3 подальшим осадженням.

У дослідженні використовувалися грані з кутом $150^{\circ}$ і відносна їх глибина d/D становила $25 \%$; $20 \%$ та $15 \%$. Ступінь заковування отвору після осадження профільованих чотирипроменевих заготовок на 50 \% показано на рис. 2 та 3.

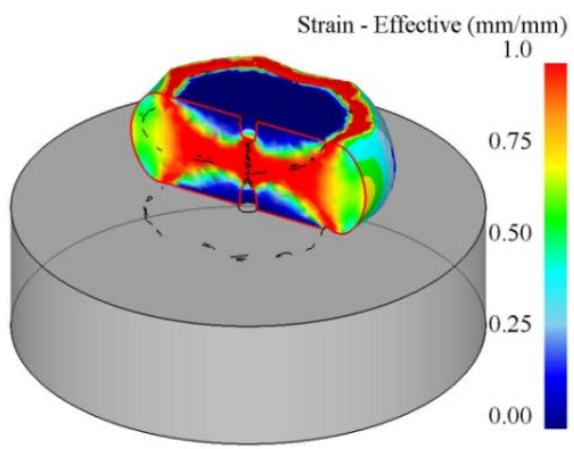

Рис. 2. Заковування отвору після осадження профільованих чотирипроменевих заготовок на $50 \%$ : $a-\mathrm{d} / \mathrm{D}=25 \%$; $\sigma-\mathrm{d} / \mathrm{D}=20 \% ; в-\mathrm{d} / \mathrm{D}=15 \%$

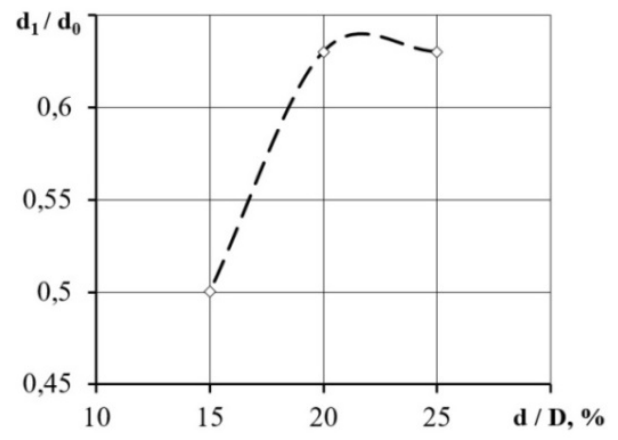

Рис. 3. Залежність відносного діаметру отвору у процесі осадження чотирипроменевих моделей 3 різною відносною глибиною граней 
Аналіз отриманих результатів дозволив встановити, що відносна глибина граней більше за $15 \%$ не призводить до збільшення ступеня заковування дефекту. Після осадження чотирипроменевих заготовок $3 \mathrm{~d} / \mathrm{D}=15 \%$ на $50 \%$ відбувається заковування середнього відносного діаметру $\left(\mathrm{d}_{1} / \mathrm{d}_{0}\right)$ дефекту на $50 \%$ (рис. 3 ).

Свинцеві зразки з отвором протягувались на чотирипроменевий переріз з під’єднаним гнучким шлангом (рис. 4, а). Після чого отримані заготовки осаджувалися для можливості фіксування об'єму внутрішньої порожнини (рис. 4, б). Змінення відносного діаметру осьового отвору при осадженні свинцевих моделей з кутом граней $150^{\circ}$ представлено на рис. 5 .

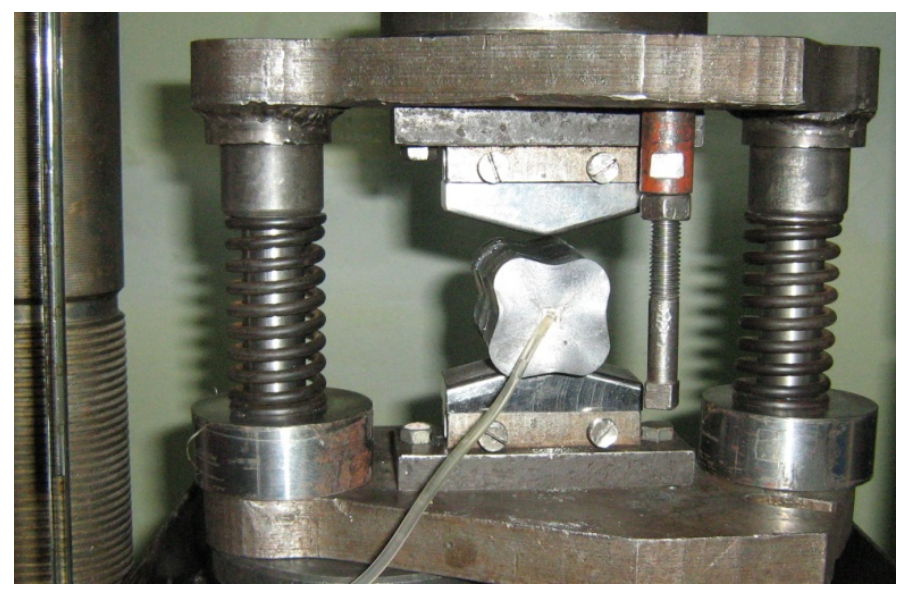

a

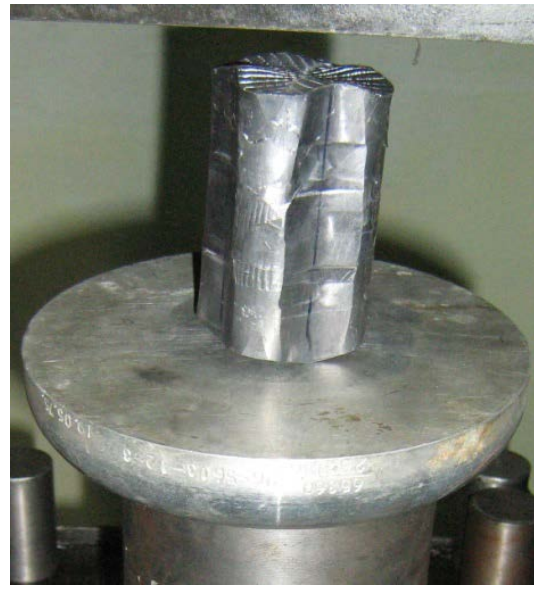

6

Рис. 4. Експериментальне дослідження на свинцевих зразках:

a-протягування на чотирипроменевий переріз; б - осадження чотирипроменевої заготовки

Дослідження заковування отвору при осадженні чотирипроменевих заготовок на свинцевих зразках перевірялись деформуванням зразків зі сталі 70ХЗГНМФ у гарячому стані. Нагрівання сталевих зразків проводилося до температури $1150{ }^{\circ} \mathrm{C}$ з подальшим їх протягуванням на чотирипроменевий переріз інструментом 3 клиновим профілем 3 кутом $150^{\circ}$ зі ступенем деформації 20 \% та кантуванням на $90^{\circ}$ (рис. 6, а).

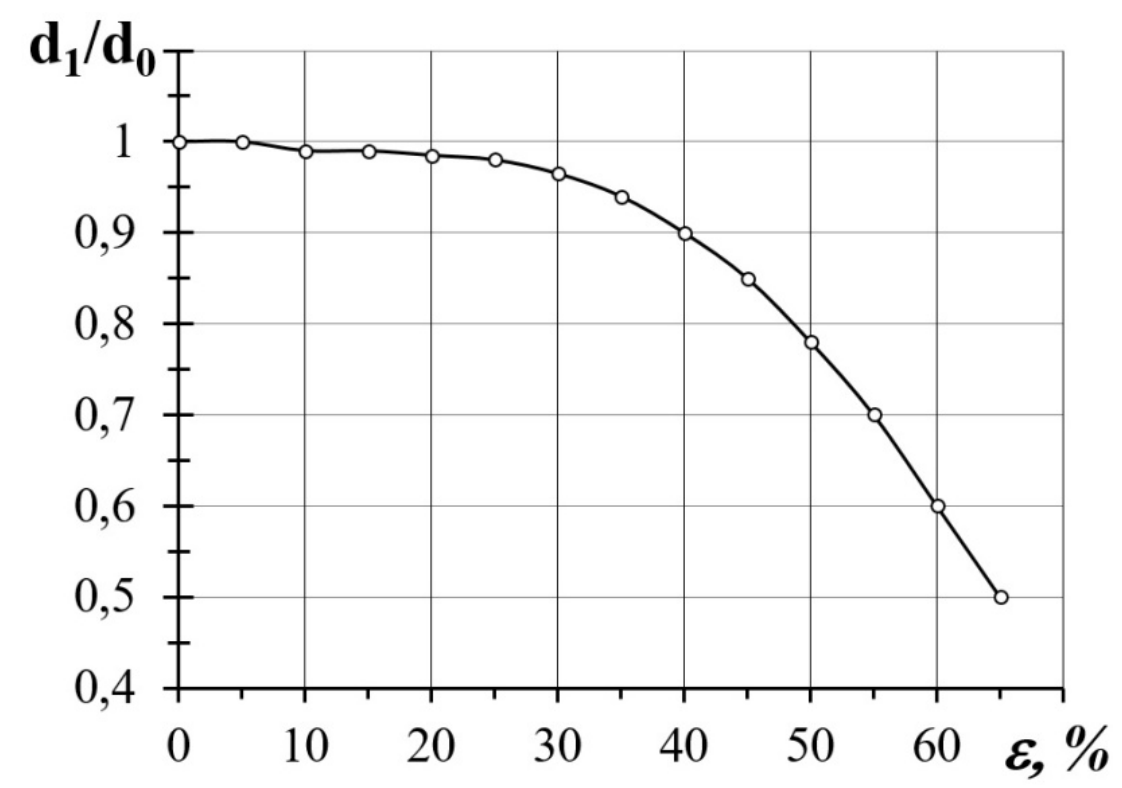

Рис. 5. Змінення відносного діаметру осьового отвору при осадженні свинцевих моделей з кутом граней $150^{\circ}$ 


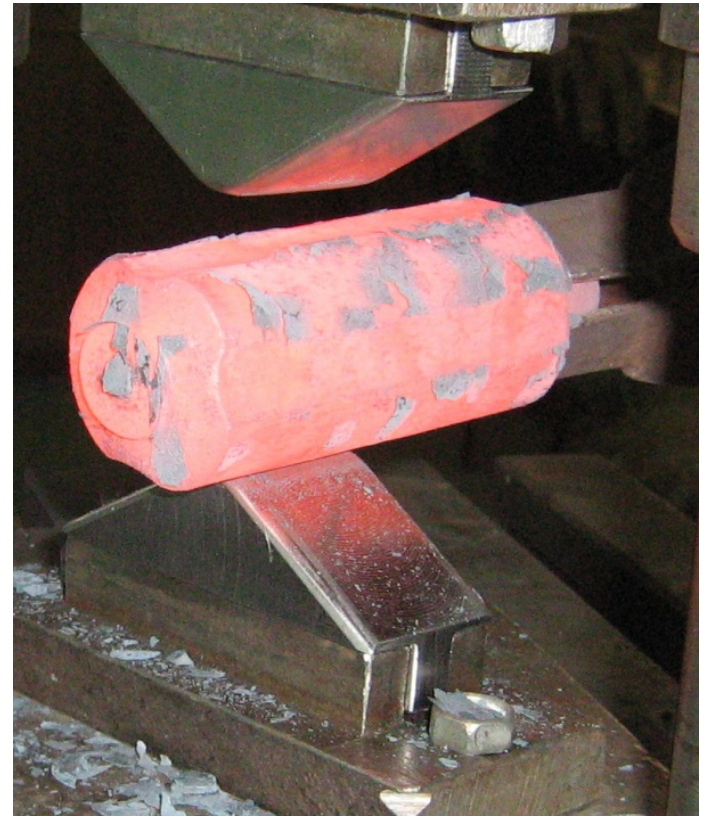

a

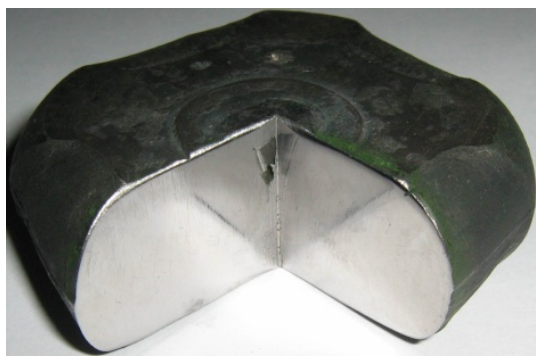

6

Рис. 6. Експериментальне дослідження на сталевих зразках:

a - протягування на чотирипроменевий переріз; б - форма отвору після осадження чотирипроменевої заготовки

Після додаткового підігрівання заготовки здійснювалось осадження. Далі зразки охолоджувалися та розрізалися до місця розташування дефекту (рис. 6, б).

На основі аналізу результатів макроструктурного дослідження визначено, що при осадженні чотирипроменевої заготовки з кутом граней $150^{\circ}$ не відбувається повного заковування штучного дефекту (рис. 6, б).

Профілювання заготовки на чотирипроменевий переріз опуклим деформуючим інструментом з кутом $150^{\circ}$ і глибиною граней 20 \% від діаметру заготовки та подальше осадження сприяють заковуванню отвору дефекту. Однак після осадження на 65 \% відносний діаметр дефекту зменшується всього лише на 50 \%. Встановлена закономірність співпадає 3 даними, що були встановлені при скінчено-елементному моделюванні.

Проведені дослідження $є$ продовженням роботи [1] в якій було визначено, що кут граней чотирипроменевої заготовки $120^{\circ}$ не призводить до повного заварювання внутрішньої пористості злитка. Тому необхідно було продовжити пошук ефективної геометрії чотирипроменевої заготовки, які підвищать величину напружень що стискають в металі заготовки.

Досліджено новий спосіб осадження чотирипроменевих заготовок з кутом граней $150^{\circ}$ та різними глибинами цих граней. За результатами дослідження встановлено закономірності зміни розмірів осьового отвору у процесі осадження. Аналіз отриманих результатів дозволив встановити ефективні рекомендації процесу осадження та його переваги перед існуючим способом деформування:

- Заковування отвору починає відбуватися при деформації 10 \%. Максимальне заковування отвору відбувається після осадження на $65 \%$ для відносної глибини граней $15 \ldots 20 \%$ від діаметра заготовки. Увігнуті грані величиною $15 \%$ від діаметра заготовки призводять до виникнення у тілі заготовки стискаючих напружень після осадження на 55 \%, що підтверджується показником напруженого стану на рівні $-10 \ldots-11$.

До обмежень розробленого способу осадження чотирипроменевих заготовок слід віднести:

- підвищення ступеня обтискання граней чотирипроменевої заготовки призводить до зниження величини напружень, що стискають в тілі поковки; 
- запропонований спосіб осадження не вирішує проблему утворення випуклої бочки, що може призводити до появи поверхневих тріщин.

Встановлені у роботі рекомендації з геометричних параметрів $\epsilon$ значимими науковотехнічними результатами, які можна використовувати в теорії та технології процесів кування крупногабаритних поковок.

Наукова новизна розробки:

- отримав подальший розвиток процес осадження чотирипроменевих заготовок;

- встановлені залежності змінення форми отвору під час осадження чотирипроменевих заготовок, які дозволили визначити ефективні параметри чотирипроменевих заготовок.

Практичним аспектом використання результатів дослідження є удосконалення техпроцесу кування крупногабаритних поковок.

Визначений підхід щодо підвищення щільності внутрішньої будови крупногабаритних поковок на базі використання способу осадження чотирипроменевих заготовок з кутом $150^{\circ} \epsilon$ продовженням тих досліджень, які були представлені у роботі [1]. Однак у роботі не представлено комплексний влив профілювання циліндричної заготовки на чотирипроменевий переріз та подальше ії осадження на НДС та ступінь заварювання внутрішніх пустот. Тому подальші дослідження слід буде направити на проведення досліджень комплексного впливу операцій профілювання та подальшого осадження чотирипроменевих заготовок для визначення ступеня заковування пустот.

\section{ВИСНОВКИ}

Проведено аналіз основних показників якості крупногабаритних поковок базових техпроцесів кування і обгрунтовано напрямок їх подальшого вдосконалення. Цей напрямок полягав в удосконаленні способу осадження чотирипроменевих заготовок.

Розроблено методику досліджень операцій профілювання і осадження чотирипроменевих заготовок, яка дозволила встановити ступінь заварювання внутрішніх дефектів.

Встановлено вплив кута граней чотирипроменевих заготовок $150^{\circ}$ на розподіл деформацій, температур, напружень і заварювання внутрішніх пустот після осадження. Заковування отвору починає відбуватися при деформації 10 \%. Максимальна заковування отвору відбувається після осадження на 65 \% при відносній глибині граней $15 . .20$ \% від діаметра заготовки. Увігнуті грані глибиною 15 \% від діаметра заготовки після осадження на 55 \% призводять до виникнення у тілі заготовки стискаючих напружень на рівні $-10 \ldots-11$.

Розроблено новий науково-обгрунтований спосіб осадження чотирипроменевих заготовок, який підвищує якість крупногабаритних поковок.

На основі проведених комплексних теоретичних і експериментальних досліджень розроблені технологічні та конструкторські рекомендації з проектування техпроцесів кування за новими схемами деформування і інструменту для профілювання злитків.

\section{REFERENCES}

1. Markov O.E. Forging of Large Pieces by Tapered Faces. Steel in Translation. 2012, 42, pp. 808 - 810. DOI: https://doi.org/10.3103/S0967091212120054

2. Dudra S. P., Im Y. T. Analysis of void closure in open-die forging. International Journal of Machine Tools and Manufacture. 1990, 30(1), pp. 65-75. DOI: https://doi:10.1016/0890-6955(90)90042-H

3. Chen K., Yang Y., Shao G., Liu K. Strain function analysis method for void closure in the forging process of large sized steel ingot. Computational Materials Science. 2012, 51(1), pp. 72-77. DOI: http://dx.doi.org/ 10.1016/i.commatsci.2011.07.011

4. Zhbankov I.G., Markov O.E., Perig A.V. Rational Parameters of Profiled Workpieces for an Upsetting Process. International Journal of Advanced Manufacturing Technology. 2014, 72, pp. 865-872. DOI: https://doi.org/10.1007/s00170-014-5727-5

5. Nakasaki M., Takasu I., Utsunomiya H. Application of hydrostatic integration parameter for free-forging and rolling. Journal of Materials Processing Technology. 2006, 177(1-3), pp. 521-524. DOI: https://doi:10.1016/ j.jmatprotec.2006.04.102 
6. Markov O.E., Perig A.V., Zlygoriev V.N., Markova M.A., Grin A.G. A new process for forging shafts with convex dies. Research into the stressed state. International Journal of Advanced Manufacturing Technology. 2017, 90, pp. 801 - 818. DOI: http://doi.org/10.1007/s00170-016-9378-6

7. Chen M-S., Lin Y.C. Numerical simulation and experimental verification of void evolution inside large forgings during hot working. International Journal of Plasticity. 2013, 49, pp. 53-70. DOI: http://dx.doi.org/10.1016/j.ijplas.2013.02.017

8. Markov O.E., Perig A.V., Zlygoriev V.N., Markova M.A., Kosilov M.S. Development of forging processes using intermediate workpiece profiling before drawing: research into strained state. Journal of the Brazilian Society of Mechanical Sciences and Engineering. 2017, 39(4), pp. 4649-4665. DOI: https://doi.org/10.1007/S40430-017-0812-Y

9. Sheikhi S., Rech R., Wahlers F., Bokelmann D., Wupperman C., Bonfig K. W., Notzel R., Steingier K. J. Fortschrite beim Freiformschmieden in den letzten 25 Jahren. Stahl und Eisen. 2010, 1, pp. 2-14.

10. Aksakal B., Osman F. H., Bramley A. N. Determination of experimental axial and sideways metal flow in open die forging. Material and Design. 2008, 3, pp. 576-583.

11. Christiansen P., Martins A. F., Bay N., Hattel J.H. Multi-objective optimization of die geometry in ingot forging. Procedia Engineering. 2014, 81, pp. 2457-2462. DOI: https://doi:10.1016/j.proeng.2014.10.350

12. Cho J. R., Bae W.B., Kim Y.H., Choi S.S., Kim D. K. Analysis of the cogging process for heavy ingots by finite element method and physical modeling method. Journal of Materials Processing Technology. 1998, pp. $80-81,161-165$.

13. Kakimoto H., Arikawa T., Takahashi Y., Tanaka T., Imaida Y. Development of forging process design to close internal voids. Journal of Materials Processing Technology. 2010, 210(3), pp. 415-422. DOI: http://dx.doi.org/10.1016/ j.jmatprotec.2009.09.022

14. Kun C., Yitao Y., Guangjie S., Kejia L. Strain function analysis method for void closure in the forging process of large sized steel ingot. Computational Materials Science. 2012, 51(1), pp. 72-77. DOI: http://dx.doi.org/ $\underline{10.1016 / j . c o m m a t s c i .2011 .07 .011 ~}$

Марков О. С. - д-р техн. наук, зав. каф. КДіМПМ ДДМА;

E-mail: oleg.markov.omd@gmail.com

ORCID: 0000-0002-2467-9607

Злигорєв В. М. - канд. техн. наук, головний металург ПрАТ «НКМЗ»;

E-mail: zvn@nkmz.donetsk.ua

ORCID: 0000-0001-5306-3812

Іванова Ю. О. - аспірант ДДМА;

E-mail: yachmen.yuliya@gmail.com

ORCID: 0000-0002-4145-9665

Лагер О. О. - магістрант ДДМА;

E-mail: lager.aleksandr@mail.ru

ORCID: 0000-0003-2546-7240

Дорофєєв В. О. - магістрант ДДМА;

E-mail: vlad.dorofey.98@gmail.com

ORCID: 0000-0001-5766-1684

ДДМА - Донбаська державна машинобудівна академія, м. Краматорськ.

ПрАТ «НКМЗ»- Приватне акціонерне товариство «Новокраматорський машинобудівний завод», м. Краматорськ. 